\title{
The Absurd Theme in "A Good Man is Hard to Find”
}

\author{
Yang Zhao \\ Foreign Languages College, Beihua University, Jilin 132013, China.
}

Keywords: Absurdity, Alienation, Human nature, Metaphor.

\begin{abstract}
Flannery O'Connor is a celebrated $20^{\text {th }}$ century American woman writer. Her stories seem to be easy and humorous; actually they are shocking and startling. Irregular plot, blood and violence, gloomy religion, typical southern setting, together with groups of freakish, demonic people enchant O'Connor's works with special glamour. Her short novel "A Good Man is Hard to Find” is her most highly regarded work. This paper focuses on the analysis of main characters, plots and some symbolic details and images in order to interpret O'Connor's metaphoric elaboration and exploitation of this absurd theme, and help readers sufficiently comprehend this philosophical theme that has thoroughly exposed absurdity and hypocrisy of morality and civilization in western society
\end{abstract}

\section{Introduction}

For most critics of literature who believe that this Catholic writer only has one story to tell, O'Connor draws the conclusion that the family's tragedy caused by "the Misfit" is a tale concerning original sin and redemption. For critic Jefferson Harm- sworth, "the Misfit” has sent grandmother to heaven, and another critic, Claude Richard holds the same opinion, he points out that the grandmother acquires "moment of grace" from God. Definitely, redemption is the noticeable theme of "A Good Man is Hard to Find", whereas it is not the exclusive theme. The critic Susan Paulson once comments that after reading the stories of O'Connor in a meticulous way, readers will appreciate the values of Catholicism as well as certain regularity of modern philosophy and development of human being's psychology. Without any skepticism, Susan asserts there is indeed philosophic theme in O'Connor's works. In terms of this novel “A Good Man is Hard to Find”, the protagonists, plot and some inscrutable details or images all imply O’Connor's elaboration and exploitation of this philosophical theme-absurdity.

\section{The metaphoric elaboration and exploitation of absurdity}

In "A Good Man is Hard to Find”, grandmother considers herself as a modern people from a "civil society", and never realizes the absurdity in her life, on the contrary , she is always optimistic and believes she is capable of grasping the nature of life, therefore she frequently exhibits her extreme desire for controlling power. She insists that Tennessee, the vacation destination that she has chosen for her family, is a "civil place", it represents her "conscience" and it is a place that can educate children and broaden their horizon. Another vital reason for grandmother's unwillingness to Florida but Tennessee is "Here this fellow that calls himself The Misfit is a loose from the Federal Pen and headed toward Florida", she feels reluctant to take children to such a dangerous place to spend their holiday, if she does, she will suffer a hard time to comfort her own conscience.

She is eager to disguise herself as an advisable, elegant and well-educated lady, while virtually; she is an ultra-hypocritical, tyrannical and self-centered old woman, which can be detected from a detail in the novel: grandmother is well aware that "Her son, Bailey, didn't like to arrive at a motel with a cat." However, she still takes her cat along secretly in the car and figures out a seemingly reasonable and humanistic excuse for herself that "She didn't intend for the cat to be left alone in 
the house for three days because he would miss her too much and she was afraid he might brush against one of her gas burners and accidentally asphyxiate himself.”

Absurdly, though grandmother arranges everything with painful care, the unpredictability and contingency of reality often inverse with her logic and will. She insists on traveling to Tennessee to avoid encountering "The Misfit", and meanwhile to educate the children, it is her decision that results in the family's tragedy; she takes her cat with family for fear that it may accidentally asphyxiate itself, yet at last, it is the cat that causes a turnover that exposes the family in front of “The Misfit” without any protection.

If O’Connor has portrayed grandmother so close to life that it is laborious for readers to apprehend the absurdity of grandmother's life, the absurd portrayal of "The Misfit" is dramatically conspicuous. Actually, "The Misfit” is also a "normal person” from this "civil society". He says "God never made a finer woman than my mother and my daddy's heart was pure gold" and "I never was a bad boy that I remember of". Unlike those who can live their whole life out without asking about it, "The Misfit” attempts to clarify his life through various experience: he was a gospel singer for a while, he has been in the arm service both land and sea, at home and abroad, been twice married, been an undertaker, been with the railroads, plowed Mother Earth, been in a tornado, seen a man burnt alive once and even seen a woman flogged. Unfortunately, like the hero in Camus's novel, since he is confronted with this forever chaotic and incomprehensible world, all of his effort to comprehend the life has been doomed to be a failure, thus he is frequently haunted by the feeling that someone is chasing him, but he even can not figure our who and why.

As far as "the Misfit" is concerned, world is a huge jail in which he has been confined as a prisoner- "Turn to the left, it was a wall. Look up it was a ceiling; look down it was a floor." He has no access to outer world and is overwhelmed by delusion that he has been buried as a corpse. "The Misfit" is "the deformed" whose personality has been distorted in western society. He is put into prison for his villainy and he confesses that "they had the papers on me", while he cannot devise what crime he has committed on earth. It was a head-doctor at the penitentiary once tells him that he has killed his father; however, "The Misfit" reckons that as a lie, for "My daddy died in nineteen ought nineteen of the epidemic flu and I never had a thing to do with it. He was buried in the Mount Hopewell Baptist churchyard and you can go there and see for yourself.” During his imprisonment, although "the Misfit" is trying to remember what he has done by his own logic and rationality which become powerless in front of the cruel reality, he can not recall it to this day.

"The Misfit" has an unintelligible and irrational fear that children often make him nervous, and he believes only through crazy and violent means he can chase down the meaning of existence and life. Due to this reason, disregards grandmother's pathetic plea, he kills six people without any mercy. In O'Connor' eye, violence is a powerful means to bring redemption to her characters, as she explains the function of violence in a lecture on her own works: "I have found that violence is strangely capable of returning my characters to reality and preparing them to accept their moment of grace, their heads are so hard that almost nothing else will do the work." It provides the possibility of their salvation. To be saved, one has to experience a crucifixion of the old self. "The Misfit" eloquently explains this point: "she would have been a woman if it had been somebody there so shoot her every minute of her life." Indeed, all human nature vigorously resists grace because grace changes us and the change is painful, it is after violence destroys the old self that the protagonist gets the revelation, realizes his limitation as a human being and accepts grace. Thus, O'Connor portrays "the Misfit", a devil with satanic soul, to assist grandmother in acquiring moment of grace at the last minute of her life. To "the Misfit", grandmother's touch is like the bite of a snake, the gesture of recognition and acceptance signals her death. "The Misfit" denies the Resurrection in deed yet seems finally to imply a desire for acceptance; the grandmother denies it in word, perhaps, but clearly accepts it in deed, as she realizes that she is tied to "the Misfit" with a bond of mystery to which she has only paid lip service, she does the right thing, she utters the first honest words she has said to him in their brief encounter: "Why you are one of my babies. You are one of my own children." However, as this does nothing to save her, and as she is immediately shot, the readers are likely to be thrown off. This is O’Connor' pride as a writer, for which she had been 
criticized in her day by more orthodox elements in the church who would, no doubt, have wanted a clear moral position to emerge from her work.

Actions of "the Misfit" also demonstrate a complete lack of essential connection between conventional behavior and some fundamental standard of good and evil that is assumed to lie behind it. He apologizes for not wearing a shirt in the presence of ladies, and he asks the children's mother to accompany his companions into the woods to be shot with the utmost politeness. Because of the extreme incongruity between his demeanor and his actions, his actions are not only felt as an intrusion of violence, which temporarily destroys order, but as an intrusion of meaninglessness, which questions the existence of any foundation on which order can be built. As a whole, through violence of this satanic protagonist, O'Connor conveys her own profound experience of real life that is how numb people have become towards their absurd circumstance in this "civil society".

As to the portrayal of these two characters, O’Connor believes that "drawing large and startling figure" is "to make her vision apparent by shock." So the inscape of the characters themselves is the "territory held largely by the devil," in which she occupies herself with showing "the action of grace." In order to interpret the absurd theme in "A Good Man is Hard to Find" completely, however, in addition to an analysis of characters, it is essential to make a thorough exploration of several symbolic details or metaphorical images in the work.

In the first place, grandmother' family lacks emotional connection and devotional communication, these arrogant and smug individuals make their blood line fragile under outsiders' attack, with the result of shocking but reasonable death. During the trip, grandmother's son Bailey drives car without saying a word, his wife holds their children silently, even after the car accident, Bailey has no reaction other than irritation, he does not care about the safety of his children, as to the two spoiled, disrespectful brats, they feel disappointed after discovering nobody injured in the turnover. Perhaps, from the beginning, this unexpected familial estrangement, the incomplete membership, indifferent relationships and inconsistent attitudes in the family, is doomed to have an imminent disaster upon the seemingly settle life. Through these unacceptable indifference and estrangement among family members, readers can deeply perceive alienation of human nature and absurdity of life.

\section{Conclusion}

Flannery O'Connor's fictional world may well convince, or may well repulse. It is nonetheless a profound insight into human reality. In the age of existential angst and the eclipse of traditional belief, O’Connor still works with determination to bring her faith-the Christianity into clear dramatic focus. Though the message she intends for her readers may be strongly biased, she employs the particular milieu with her unique vision to reveal the truth about the human condition, and we can still have her courage and determination in standing up to her own faith.

\section{References}

[1] Drake. Robert. Flannery O’Conner: A Critical Essay [M].Grand Rapids. Mich: William B. Erdmans, 1996.

[2] Humphires. Jefferson. Flannery O’Conner and the Aesthetic of Violence [A]. Harold Bloom. Flannery O’Conner [C]. New York: Chelsea House Publishers, 1986.

[3] Hawkes. John. Flannery O’Conner's Dail [A]. Harold Bloom. Flannery O’Conner [C]. New York: Chelsea House Publishers, 1986.

[4] Flannery O’Conner. Three: Wise Blood. A Good Man is Hard to Find. The Violent Bear it Away [A]. New York: A Signed Book (third printing),1995. 